\title{
Jak a proč stát se vědeckým časopisem?
}

\section{Vážení čtenáři,}

vítám Vás při čtení prvního čísla třetího ročníku Českého finančního a účetního časopisu. $\mathrm{Na}$ úvod letošní první předmluvy si dovolím menší zamyšlení nad tím, proč a jak vydávat vědecký časopis.

Nejdříve bych začal otázkou „Proč?“ Občas se totiž můžu setkat, a to i mezi akademickými pracovníky s názorem, že psaní vědeckých článků postrádá svůj smysl, nebot' tyto články $\mathrm{v}$ podstatě ani nikdo nečte. A pokud už se nějaký čtenář najde, tak se jedná zase jen o jiného vědce, popř. studenta, který dostane přečtení tohoto článku od svého učitele za úkol. Vědecké časopisy nenalezneme na novinovém stánku a široká veřejnost zpravidla ani netuší, že vůbec takové časopisy existují. V dnešní době, kdy se vše měří komerční úspěšností, prohrávají tyto časopisy na celé čáře. A vědecká sláva má stejnou vážnost jako zpěv slavíka v parku. Je to sice krásné, ale zpeněžit se to nedá.

Avšak popřít smysluplnost vědeckých časopisů je ve skutečnosti úplně stejné jako popřít smysluplnost samotného vědeckého výzkumu. Co se vlastně skrývá pod pojmem výzkum? Výzkum je lidská činnost nejčastěji popisovaná jako vyšetřování. Tato činnost by měla být prováděna systematicky, nejde tedy o nahodilý proces, ačkoli obojí může vést ve své podstatě ke stejným výsledkům. Archeolog, jenž se systematicky zabývá průzkumem určitého terénu a nalezne vzácný artefakt, provádí výzkum, narozdíl od osoby, která se jen tak náhodně prochází po krajině a přitom nalezne vzácný artefakt. Výzkum je činnost aktivní, na výsledky výzkumu nelze tedy pasivně čekat, ale pomocí vědeckých metod se knim musíme dopracovat. Pečlivost bude zajisté kladný rys každého výzkumu, i když nelze vyloučit, že by výzkum prováděný nedbale nemohl přinést plody vědeckého úsilí. Aby byl výzkum skutečně výzkumem, musí být prováděn za určitým účelem. To nevylučuje, aby výzkum, který byl původně určen $\mathrm{k}$ jinému účelu, nemohl přinést předem neočekávané výsledky $\mathrm{z}$ jiné oblasti.

Základní výzkum přitom narozdíl od výzkumu aplikovaného nepřináší řešení konkrétních problémů, ale tvoří jen základ pro další základní a aplikovaný výzkum. Aby výsledky tohoto výzkumu mohly být prověřené, musí proběhnout jejich náročná oponentura. Samozřejmě, že by se to dalo provést i tak, že se pár vědců někde sejde a tam tyto výsledky prodiskutuje. Pak se ale výsledky tohoto výzkumu dostanou jen k několika málo osobám. Skutečná oponentura proto vyžaduje zveřejnění výsledků, aby si výsledky výzkumu mohli přečíst všichni, kdo o to projeví zájem. V televizi, v rozhlase, v denním tisku či naučně populárních časopisech místo pro takovouto publicitu není. Naopak k tomuto účelu nejlépe slouží vědecké časopisy.

Po otázce „Proč?“ bych se nyní věnoval otázce „Jak vydávat vědecké časopisy?“ Existuje několik podmínek, které musí být splněné, aby mohl být časopis uznán odbornou veřejností za vědecký.

Za prvé, všechny články uveřejněné ve vědeckém časopisu musí projít velmi náročnou vědeckou oponenturou. Na oponenty jsou přitom kladeny velmi prŕsné požadavky, a to jednak z hlediska jejich odborné erudovanosti a jednak $\mathrm{z}$ hlediska jejich nezávislosti $\mathrm{k}$ autorovi článku. První požadavek na odbornost oponenta lze považovat za relativně snadný, nebot' každý odborník se prezentuje na veřejnosti svojí vlastní publikační činností. Relativně ovšem v tom smyslu, že někdy takový odborník není třeba ochoten napsat posudek. Zvlášst pokud 
posudky nejsou nijak zvlášt' honorované, ale kde na to má vědecký časopis brát, že ano. Druhý požadavek týkající se nezávislosti vypadá také jednoduše, dokud si ovšem neuvědomíme, že v Čechách se často jedná o tak malou vědeckou komunitu, že se v podstatě všichni navzájem velmi dobře znají. Vydáváte-li časopis $\mathrm{v}$ češtině můžete se dozvědět od oponenta, že česky na dané téma píšou pouze dva lidé, a když to tedy není on, kdo napsal tento článek, pak to tedy musí být ten druhý. A tak se hledají další cesty, jak zajistit uvedené dva požadavky. Jednak místo jednoho oponenta se vyžadují nejméně dva. Když se jeden oponent nechá autorem ovlivnit, at' už osobně nebo jeho slávou, pořád je tu ještě naděje, že ten druhý oponent napíše posudek poctivě. Proto se metody oponentury vylepšují ještě tím, že posudky jsou anonymní. Oponent neví koho posuzuje, to se dozví až po zveřejnění článku, a autor neví, kdo jeho článek posuzuje. V našem časopise jsme zavedli dva oponenty, přičemž se v rámci možností snažíme zachovat jejich nezávislost. V budoucnosti předpokládáme, že přjejeme rovněž $\mathrm{k}$ anonymnímu posuzování.

Za druhé, vědecký časopis by měl mít redakční radu složenou z vědeckých odborníků. Aby časopis nemohl být odbornou veřejností považován pouze za jakýsi laciný prostředek získávání publikačních bodů, měla by být tato rada tvořena nejen interními členy (pracovníky vydávající instituce), ale i externími členy. V zájmu splnění této podmínky jsme na začátku tohoto roku provedli rozšíření redakční rady z původních pěti členů na jedenáct. Členství v naší radě jsme proto nabídli uznávaným odborníkům z českých a slovenských univerzit a je pro nás velkým potěšením, že tuto nabídku přijali.

Za třetí, každý článek ve vědeckém časopise by měl dodržovat určitou pro tyto články obvyklou strukturu: úvod, cíl, vědecký obsah, závěr, seznam literatury, abstrakt, atd. Autor, který si nezadá ve své práci cíl, je ve stejné pozici jako běžec, který vlastně neví, kam běží. Dodržování citační etiky a poctivosti při konstrukci bibliografické citace jsou nezbytnou podmínkou, aby se dalo ještě hovořit o vlastním původním článku.

Za čtvrté, vědecký časopis má smysl pouze tehdy, pokud články v něm obsažené také někdo čte. Tištěná podoba časopisu je sice oblíbená, ale dostane se nakonec jen k několika málo čtenářùm. Často dokonce končí nepovšimnuta v regálech knihovny, nebot' běžného čtenáře tento časopis nezajímá a odborník zrovna nejde kolem příslušného regálu. Proto je náš časopis vedle tištěné podoby vydáván současně v elektronické podobě. Je volně př́ístupný na internetu a kdokoliv, kdo projeví zájem, si může stáhnout libovolný článek z kteréhokoliv čísla časopisu. $\mathrm{V}$ dnešním digitalizovaném světě je dokonce elektronická podoba stále více preferována. Ke každému časopisu patří také diskuse mezi vědci, často velmi vášnivě vedená. V rubrice recenze naleznete v tomto čísle nejprve velmi ostrou kritiku na knihu Tržni prístup $k$ ochraně životního prostředí a následně stejně ostrou odpověd' autorů této knihy na tuto recenzi. Je pravda, že bez vášnivé debaty nemůže vědecký výzkum nikam pokročit. A proto jsme se rozhodli tuto diskusi uveřejnit. Je nám ovšem líto, že jak recenzent tak autoři se při hledání argumentů pustili i do našeho vydavatele. V př́ípadě recenzenta se logicky jedná o výtku, proč vůbec byla tato kniha vydána. Myslím si ovšem, že nebýt našeho vydavatele tak by ani tato diskuse nemohla probíhat.

Za páté, vědecký časopis by měl vycházet pravidelně. Podmínka, která straší každého předsedu redakční rady. Podmínka, která se kupodivu splňuje často velmi obtížně, např. tehdy pokud nějaká instituce (at' už vládní či nevládní) v průběhu roku vypíše požadavky na uznávání časopisů za recenzované. A to byl i důvod, proč letošní rok výjimečně tento časopis vyšel až v květnu. Za což se všem našim čtenářům, kteří netrpělivě na tento časopis čekali, jménem redakční rady omlouvám. 
Cílem prvního ročníku bylo uvést Český finanční a účetní časopis do života a zviditelnit ho mezi odbornou veřejností. Cíl druhého ročníku spočíval ve zvýšení náročnosti a kvality publikovaných článků. Cílem třetího ročníku je především splnit a př́ísně dodržovat všechny požadavky, které jsou kladené na vědecký časopis, tak aby byl uznáván nejen odbornou veřejností ale i veřejnými institucemi zabývajícími se posuzováním kvality vědeckých časopisů.

\author{
prof. Ing. Petr Marek, CSc. \\ předseda redakční rady Českého finančního a účetního časopisu \\ a řešitel výzkumného záměru \\ Rozvoj účetní a finanční teorie \\ a její aplikace v praxi z interdisciplinárního hlediska
}

